\title{
A köröndi Tűz egy építőmérnök szemével III. Rész. Az Életveszélyelhárítás II. üteme, felkészülés az állagvédelemre
} The fire on the körönd by the eyes of an engineer paRt. III. The SEcond time of averting of life-danger, preparation on conservation

\section{G. LÁMER}

Debreceni Egyetem, Műszaki Kar, Műszaki Menedzsment és Vállalkozási Tanszék, glamer@eng.unideb.hu

Absztrakt. A Köröndi tűzben károsodott az Andrássy út 83-85. épület tetőszerkezete és zárófödémje. Ismertetjük a tüz okozta károkat és bemutatjuk az épületet a tüzkár utáni állapotban.

Abstract. The roof and the closing floor of the building located Andrássy Street 83-85. damaged by the fire on the Körönd. We describe the damages caused by fire, and present the state of the building after damage caused by fire.

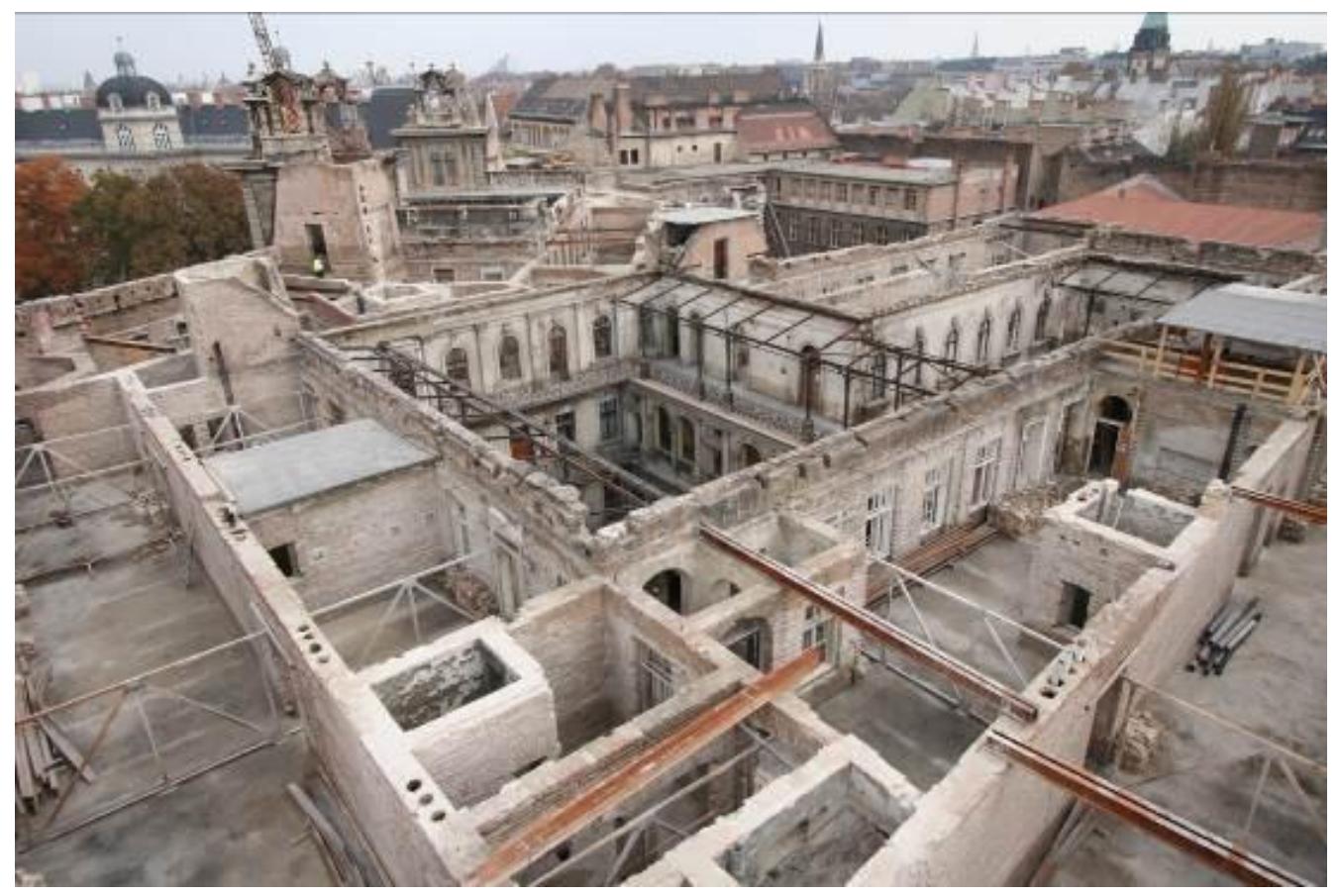

1. ábra: Áttekintő fénykép az épületről az életveszély felszámolása után 


\section{Bevezetés}

Az Andrássy út 83-85-ben 2014. július hó 15-én, az esti órákban tűz ütött ki. A tűzkárt követően szakértőként részt vettem az épület állapotának értékelésében, valamint a kialakult életveszélyes állapot felszámolásában.

Jelen tanulmánysorozat a Budapest VI., Andrássy út 83-85. sz. alatti épület tűzkár utáni állapotának értékelésével, a tűzkár után létrejött életveszélyes állapot két ütemben történt felszámolásával, és az egyes ütemeket követő állapot értékelésével foglalkozik.

Ebben a tanulmányban a belső életveszélyes állapot elhárításának folyamatát, valamint az állagvédelemre való felkészülést mutatjuk be. Az előző két tanulmányban ismertettük az épület állapotát a tüzet követően, illetve a belső életveszélyes állapot elhárításának folyamatát, valamint az életveszélyes állapot felszámolása után az épület állapotának értékelését. Egy további közleményben ismertetjük az életveszélyes állapot felszámolását követően az épület állapotának értékelését.

Jelen tanulmány-sorozat a Végleges állapotértékelő szakértői vélemény szövegén alapul. Ez úton kívánok köszönetet mondani a Budapest Főváros VI. Kerület Terézvárosi Polgármesteri Hivatal Jegyzőjének, aki hozzájárult ahhoz, hogy az esetet tudományos szempontból közzé tehessem.

\section{Az Életveszélyelhárítás II. üteme}

Az életveszélyelhárítás II. üteme alatt a III. emeletet, a belső udvarokat fenyegető veszélyes állapot felszámolását értjük. Használjuk a „belső” életveszélyelhárítás kifejezést is.

\subsection{A feladat meghatározása}

Az életveszélyelhárítás I. üteme alatt a Budapest Főváros VI. Kerület Terézvárosi Önkormányzat köztestülete határozatot hozott, hogy a tűzkárt szenvedett Andrássy út 83-85. épület III. emeletét és belső udvarokat fenyegető életveszélyes helyzetet felszámolja.

A határozat csak és kizárólag a belső életveszélyes helyzet elhárítására vonatkozott, állagmegóvásra nem.

$\mathrm{Az}$ életveszély elhárítás II. ütemének műszaki tartalmát két részre bontottuk. Az első az ideiglenes melléklétesítményeket, a második a segédszerkezetek építési és bontási, az épületszerkezetek bontási és rögzítési munkáit tartalmazza. 

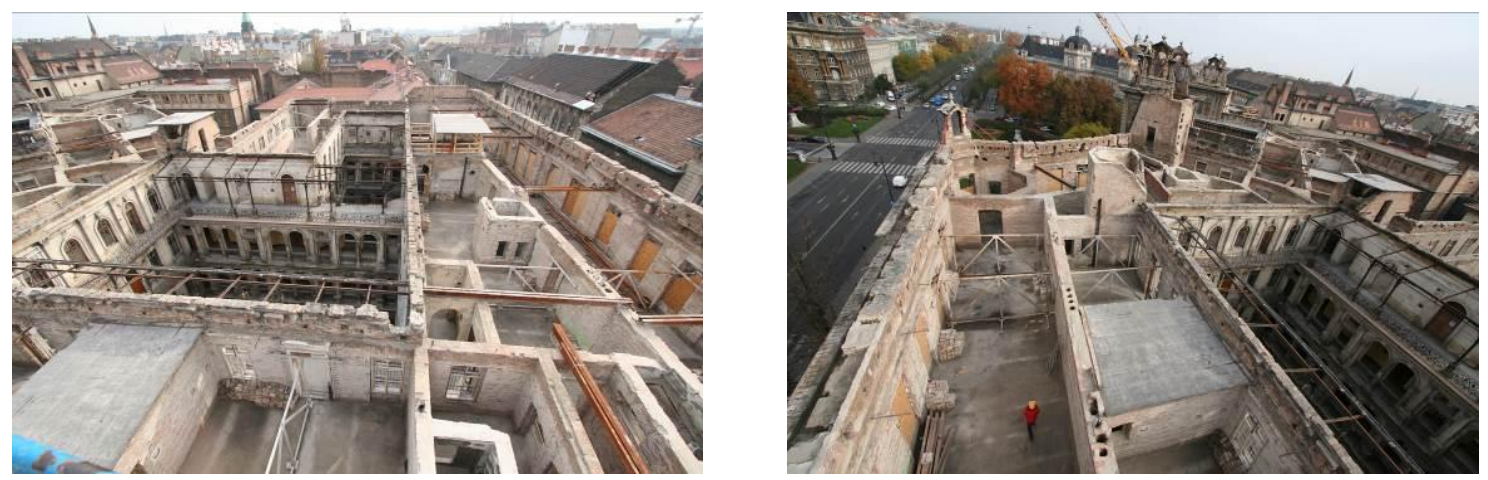

\section{2. ábra: A Szív utcai és az Andrássy úti szárnyak felülről}

Az ideiglenes melléklétesítmények közé tartozott az energiaellátás, a vízellátás biztosítása, a terület elkerítése, őrzése, a munkavégzés feltételeinek biztosítása (iroda és öltözőkonténer, mobil toalett). E munkák között kellett a fényképes dokumentációval rögzíteni az épületben a lakásajtók épségét, a csatlakozó épületek héjalásának állapotát.

A segédszerkezetek építési és bontási, épületszerkezetek bontási és rögzítési munkái tételesen rögzítették az elvégzendő feladatokat. Ezeket az elvégzett munkák alatt részleteiben ismertetjük.
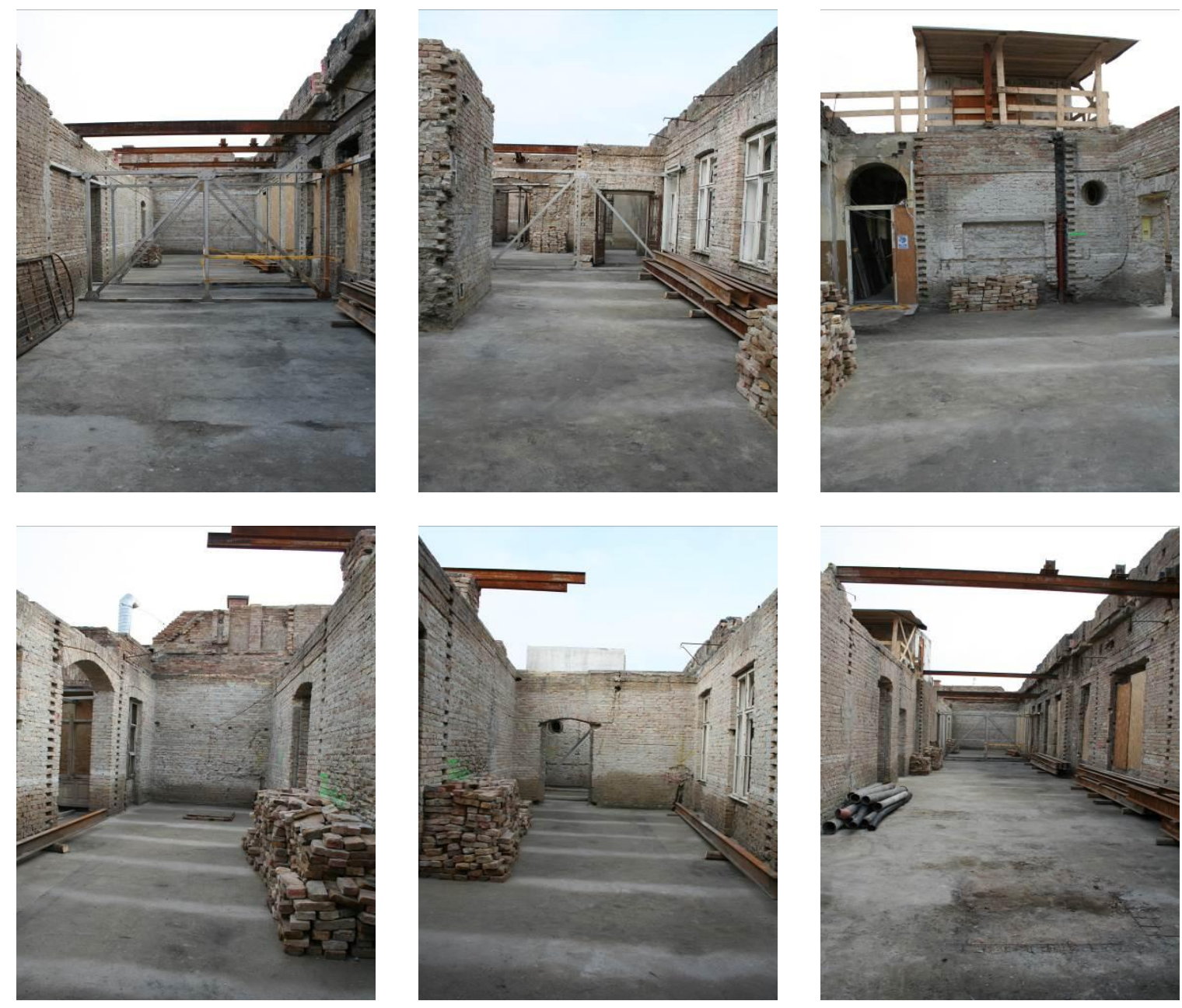

3. ábra: A Szív utca szárny belülrôl. 
A feladatok elvégzése során az alábbiakra kellett tekintettel lenni.

A Kivitelező két lépcsőházat használhatott. Az egyik a Felső erdősor utcai lépcsőház, amelyből a Felső erdősor utcai lakások is megközelíthetők. Itt szükség esetén a lakók is közlekedhettek. A második a Szív utcai lépcsőház, amelyből a lakók korábban Szív utcai és az Andrássy úttal párhuzamos belső szárnyat közelítették meg. A Kivitelezőnek, szükség esetén, a lakók számára az átközlekedést biztosítani kellett.
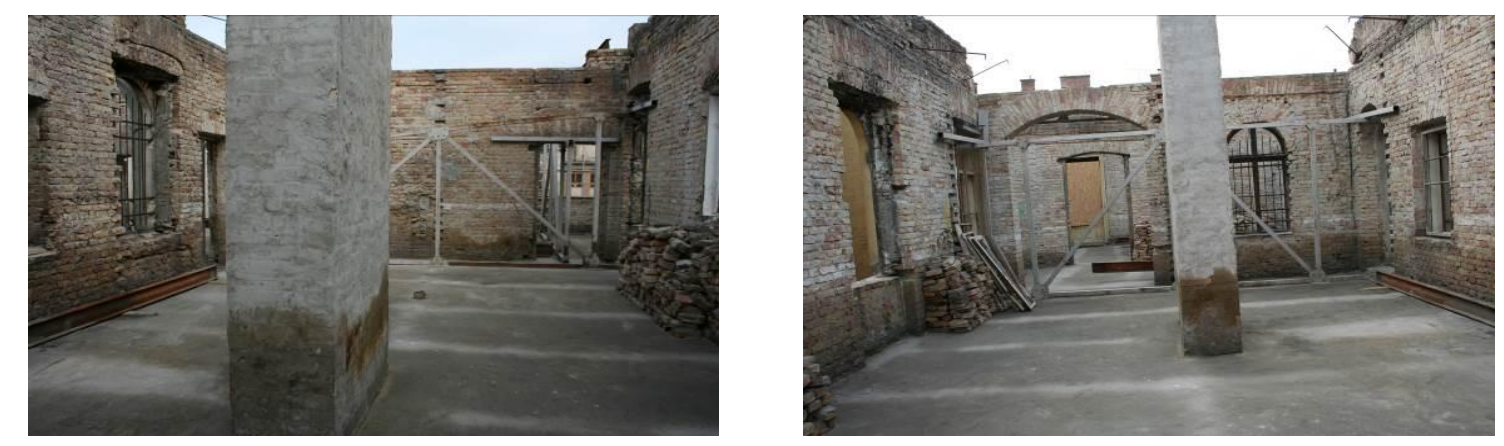

4. ábra: A Szív utcára merőleges belső szárny belülről

A Főlépcsőházat, a Köröndi szárnyban lévő lépcsőházat és a belső csigalépcsőt a lakók részére tartottuk fönn.

A lakók ingatlanjaikban keletkezett károk felmérése és az ingatlanok elszállítása esetén a lakók a nekik fenntartott lépcsőházon keresztül közelíthették meg a lakásaikat, és vihették el az ingóságaikat.

A lakók és a kárszakértők beengedését az Önkormányzat szervezte meg, a Kivitelezővel egyeztetve.

\subsection{A belső életveszélyelhárítási munkák elvégzése}

A belső életveszélyelhárítási munkák elvégzésével a VI. kerület Önkormányzat képviselő testülete a KÉSZ Zrt-t bízta meg. A KÉSZ Zrt. a külső életveszélyelhárítási munkákat 2014. augusztus hó 13-én kezdte meg és 2014. november hó 18-án fejezte be.

A szerződésben tételesen előírt, elvégzett munkák

A Kivitelező az alábbi, a szerződésben tételesen előírt munkákat végezte el.

Az ideiglenes melléklétesítményekkel kapcsolatos munkákat nem soroljuk fel, azokat hiánytalanul elvégezte. 

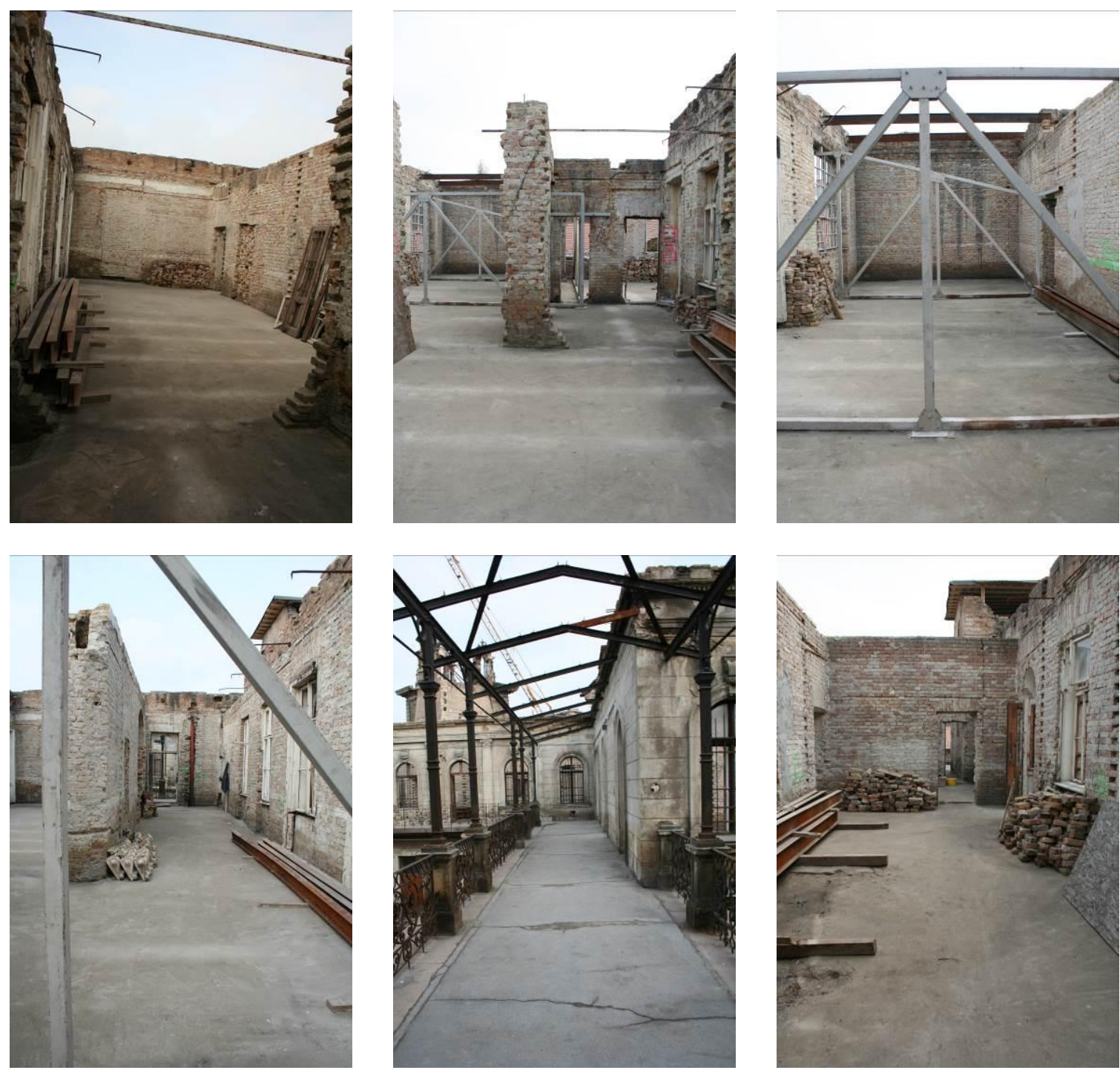

5. ábra: Az Andrássy útra merőleges belső szárny és előtte a függőfolyosó belülről

A segédszerkezet építési és bontási munkáit sem soroljuk fel. A Kivitelező alpintechnikát és emelőkosaras gépjárművet alkalmazott.

Egyes stabilizálási munkák helyett, szerződésmódosítással, a szerkezetet elbontották (kémények, légaknák falai, tűzfalak).

Az elvégzett munkák.

- Lépcsőházak lezárása ideiglenes ajtóbeépítéssel, zárható módon, a lépcsőkarok, -fordulók és pihenők takarítása

- A III. emeleti ablakok elzárása

- Védőkorlátok építése

- Lépcsőházak második emeleti része felett védőtető készítése 
- A fedélszék és a zárófödém megmaradt üszkös fagerendájának bontása. A födém és fedélszék faanyagában helyenként gombafélék telepedtek meg. Ezért a munkálatokat faanyagvédelmi szakértő bevonásával végeztünk.

- Hófogó, hágcsók, kéményjárdák, villámhárító eltávolítása
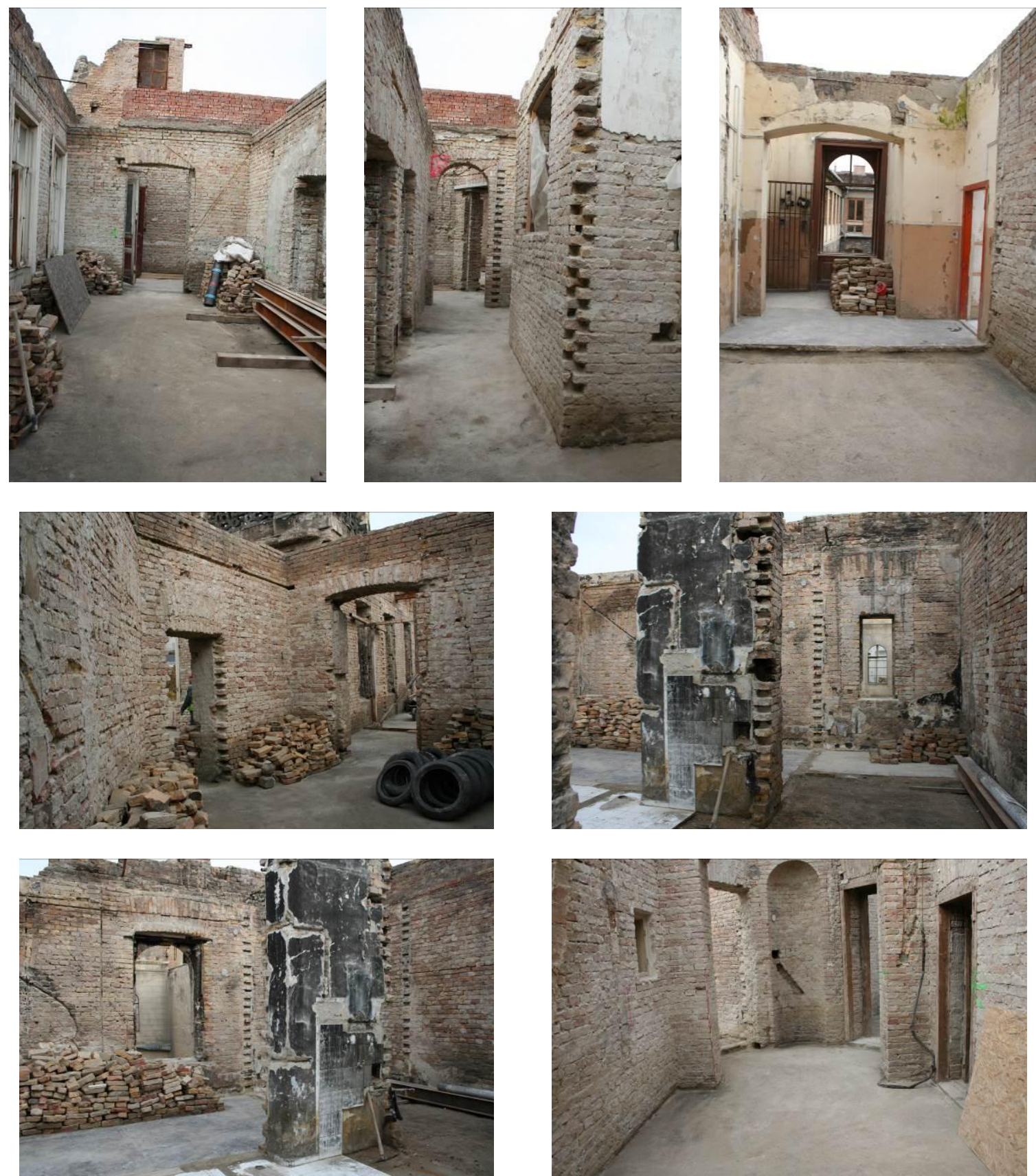

6. ábra: A Köröndi szárny belülről

- A belső párkányok megtisztítása

- Gyámolító acélgerendák bontása, deponálása a II. emeleti födémen, a főfalak mellett

- A középfőfal kéményein fennakadt bádoglemezek bontása 
- Második emelet feletti födémre hullott égett anyag, építési törmelék eltávolítása

- A két leomlott tűzfal falazó elemeinek az összegyűjtése, deponálása a II. emeleti födémen, a főfalak mellett

- Az eltört koronázópárkány bontása a Köröndi szárny közepén, a visszabontott anyag deponálása a Köröndi udvarban

- A Felső erdősor utcai lépcsőház tönkrement tetőtéri felépítmény falának visszabontása

- A Felső erdősor utcai lépcsőház tönkrement tetőtéri felépítmény vb. födémének visszabontása

- A belső udvarok megtisztítása

- A belső vízelvezetés nyitott csatorna „végeinek” elzárása a III. emeleten

- A két torony összesen hat sarkán leterhelő súly elhelyezése (bontott tégla felhasználásával, habarcsba rakva)
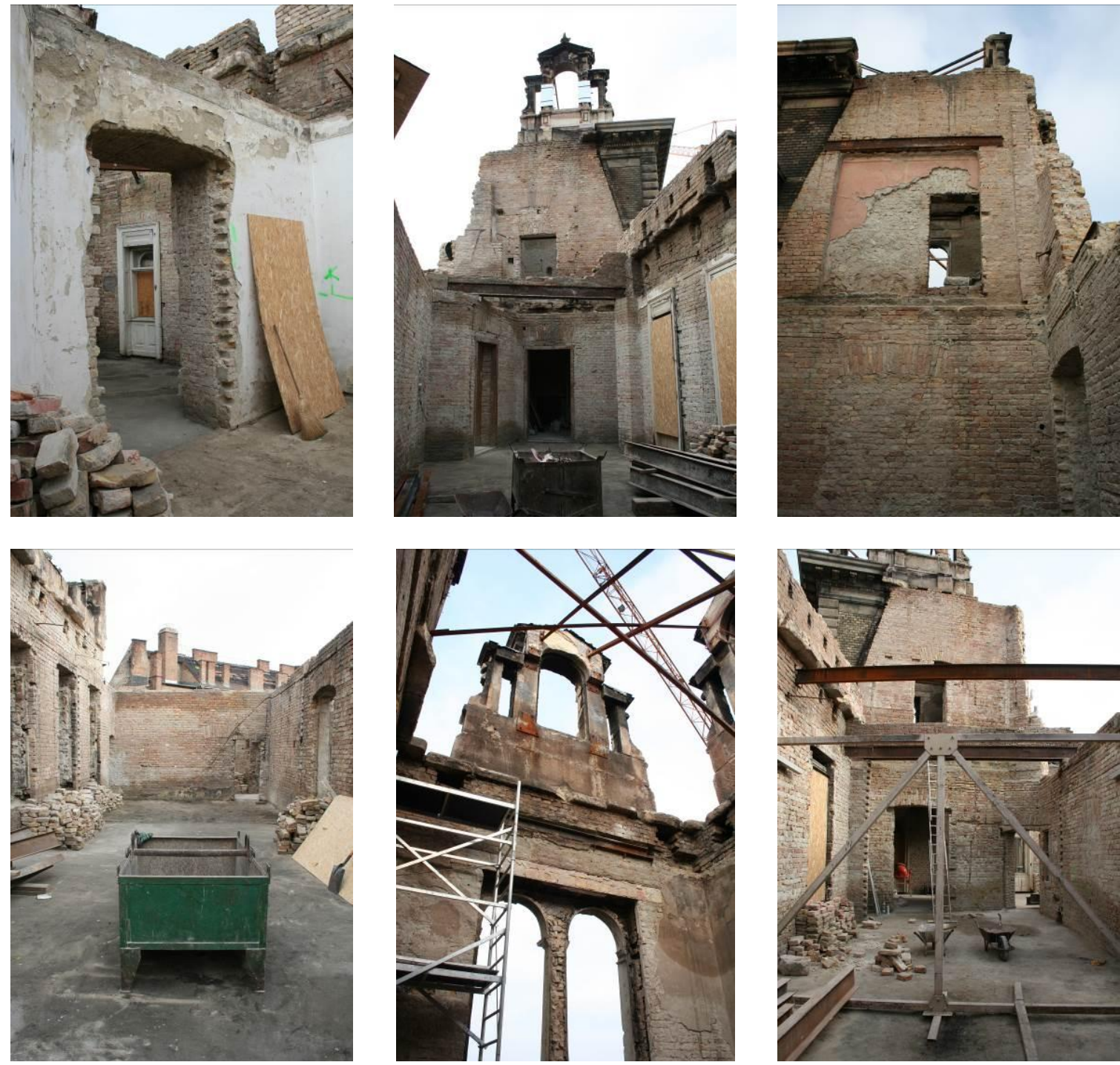

7. ábra: A Tornyok környezete és a Tornyok belülrôll 
- A koronázópárkányon leterhelő súly pótlása (bontott tégla felhasználásával, habarcsba rakva)

- A bontott anyag elszállítása kijelölt lerakóhelyre

- A bontási munkálatok során keletkezett veszélyes hulladék konténerbe rakása, épületből történő kiemelése és elszállítása kijelölt lerakóhelyre

A Kivitelező a szerződésben előírtakat maradéktalanul teljesítette.

A szerződésben áttételesen, a szakértő által a veszélytelenítés közben előírt, elvégzett munkák

A Kivitelező az alábbi, a szerződésben áttételesen, a szakértő által a veszélytelenítés közben előírt munkákat végezte el.

- Az III. emeleti instabil válaszfalakat elbontotta, a bontási anyagot a II. emelet feletti födémen deponálta.

- A Felső erdősor utcai megroggyant, életveszélyessé vált liftgépházat elbontotta, a bontási anyagot a II. emelet feletti födémen deponálta.

- A Felső erdősor utcai elbontott liftgépház helyett egy ideiglenes liftgépházat épített.

- Az Andrássyi út felőli oromdísz felső íves alakú, eltört, közvetlenül életveszélyessé vált elemét elbontotta, a francia udvarban deponálta.

- A Szív utcai liftgépház betört ablakát OSB lappal lezárta.

A Kivitelező a szerződésben áttételesen, a szakértő által pótlólagosan előírtakat maradéktalanul teljesítette.

A belső életveszélyelhárítás fegyelmezett munkavégzése során baleset nem történt.
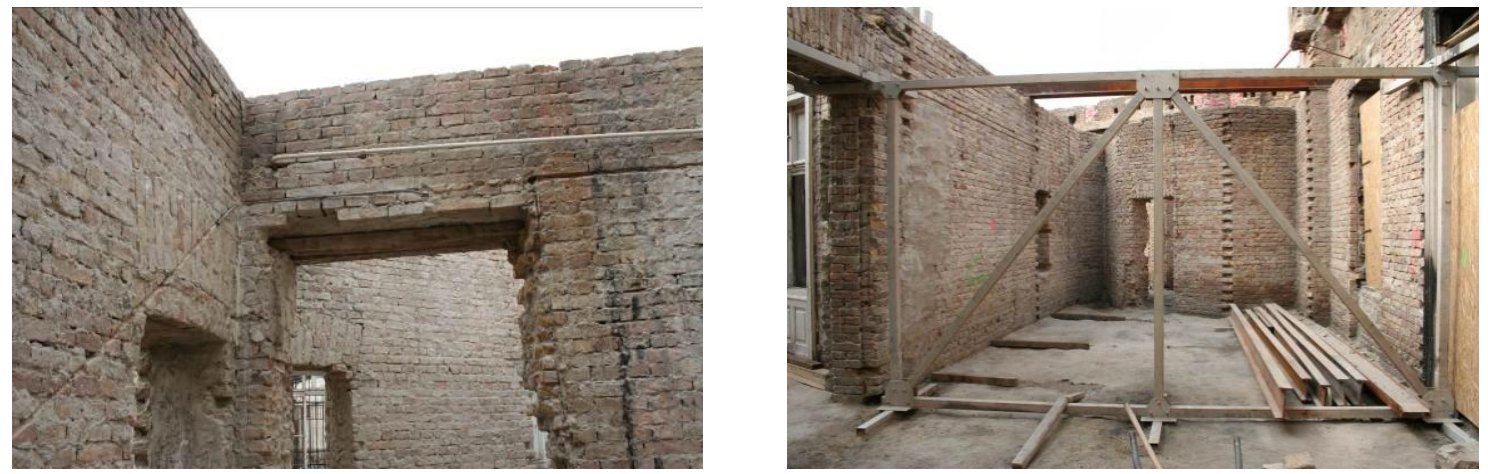

8. ábra: A Felső erdősor utcai szárny belülről

\section{Felkészülés az Állagmegóvásra}

\section{Az állagmegóvással kapcsolatos föbb események}

$\mathrm{Az}$ életveszélyelhárítás azt teszi lehetővé, hogy az épületben az emberek testi épségének veszélyeztetése nélkül lehessen benntartózkodni. Az életveszélyelhárító munkák az épület állagát nem óvják meg. 

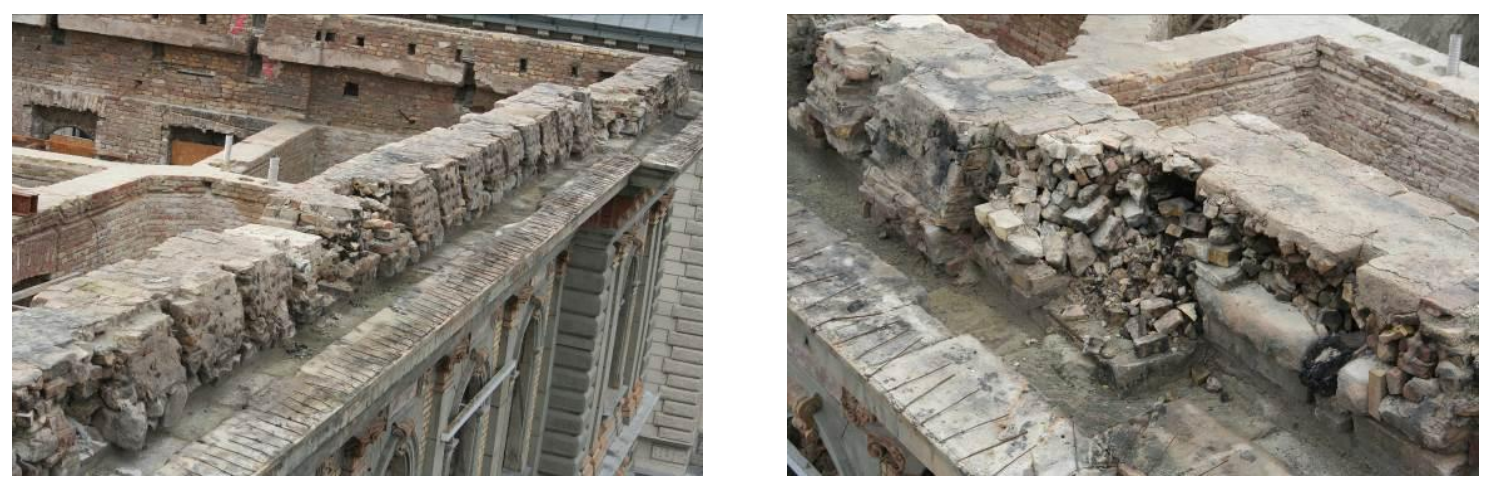

9. ábra: A megtisztított, de hibás falazatú térdfalak

Az életveszélyelhárítással egyidejűleg megkezdődött állagmegóvási munkálatok előkészítése. A Társasház tulajdonos közössége az épület fölé védőtetőt kívánt építtetni. A védőtető anyagi fedezetét a Forster Központ vállalta magára.
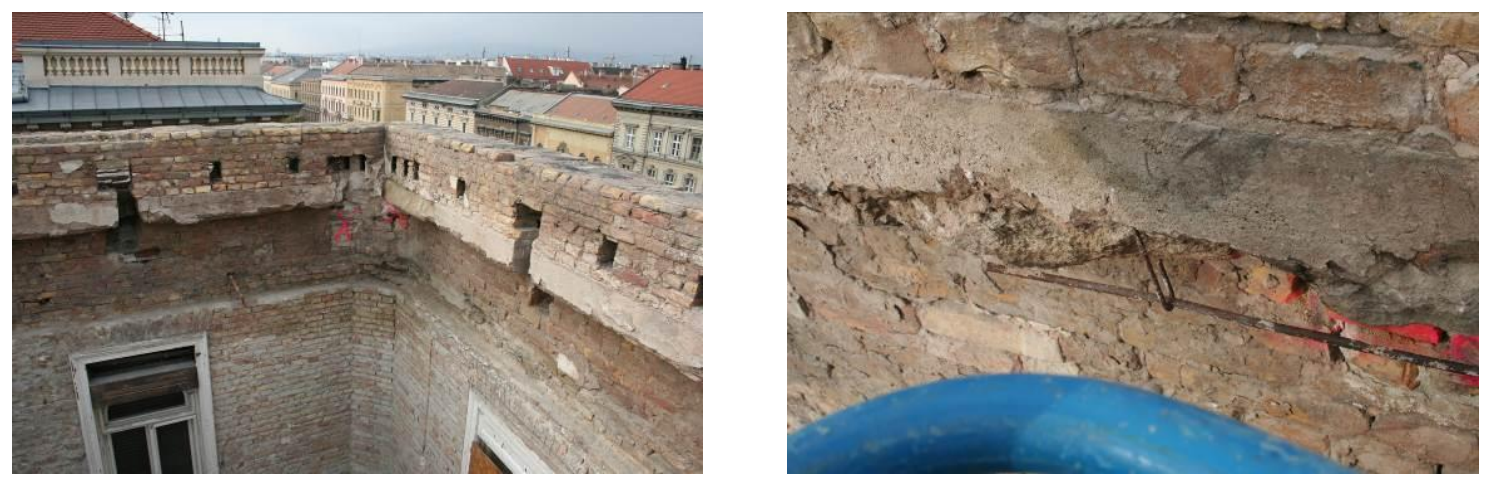

10. ábra: Korábban javított, de már a javításban is károsodott kövek a koronázópárkányban

A továbbiakban ismertetjük az állagmegóvás előkészítése kapcsán született dokumentumokat, illetve a Kivitelező szerződésének módosítása alapján elvégzett munkálatokat.

Az Andrássy út 83-85. sz. alatti épületben a tűz következtében megsemmisült a tető és a zárófödém. Ezért az épület csapadékvízzel szemben védtelenné vált. A csapadékvíz elleni védelmet egy ideiglenes tető nyújthat. 

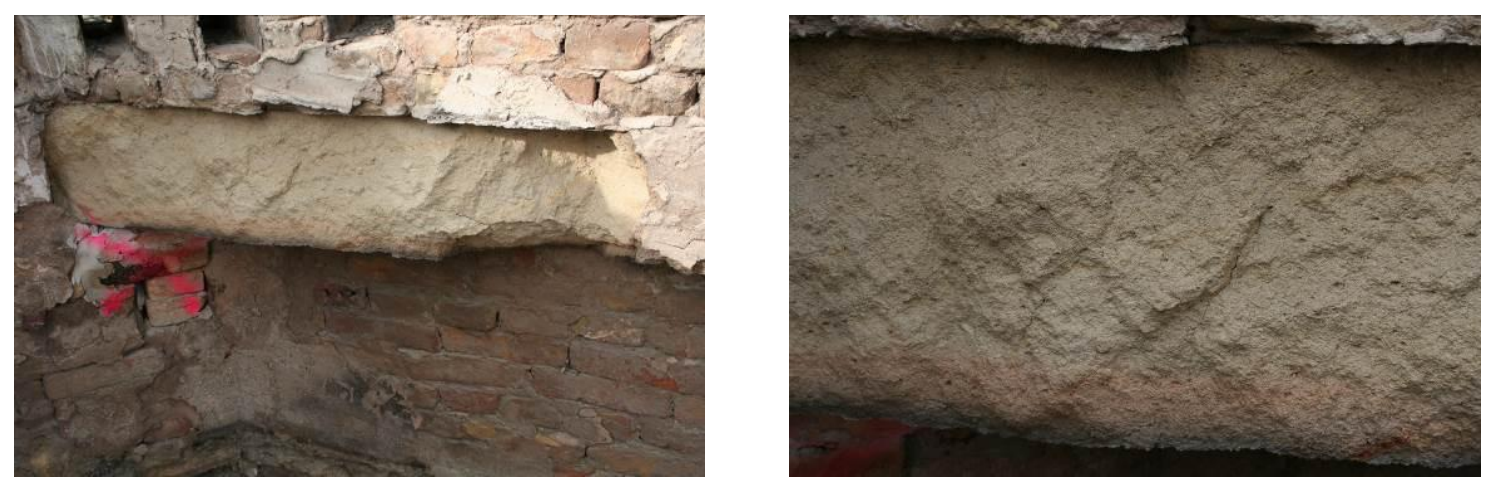

11. ábra: Károsodott kövek a koronázópárkányban

A Társasház az épület sorsával Házbizottsági ülésen foglakozott.

A Társasház részéről egy, a falakra rögzített védőtető képzeltek el. A Társasház részéről szóban több, különböző, egymástól jelentősen eltérő változat is elhangzott, például fólia, vagy ponyva fedés, trapézlemezes fedés, acélszerkezet.
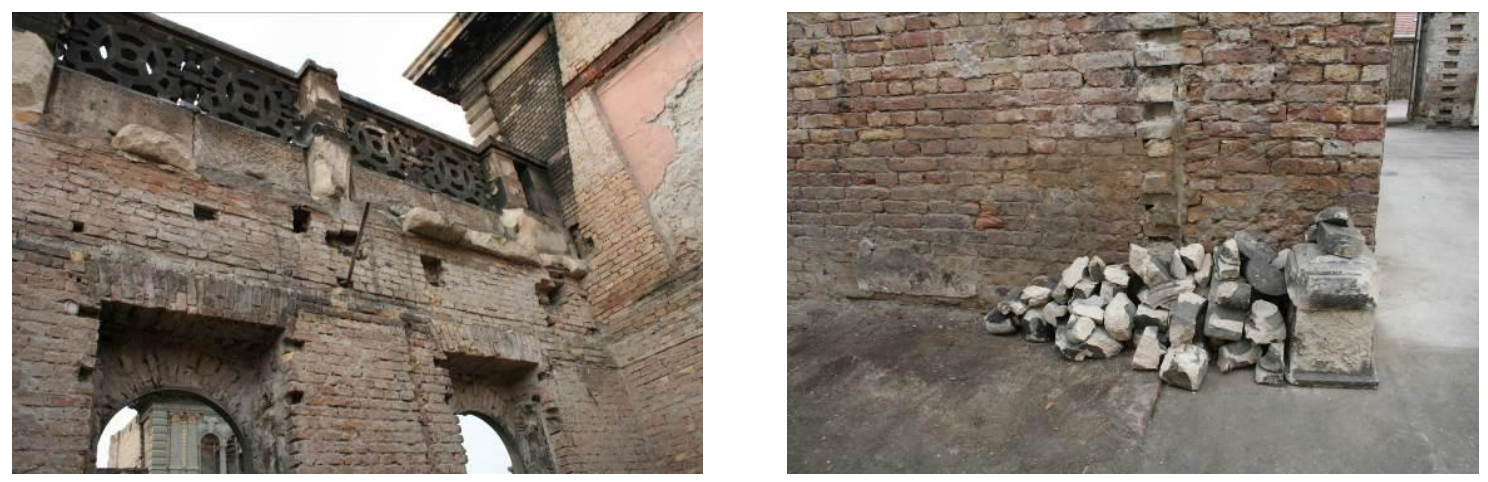

12. ábra: A károsodott kőkorlát a Köröndi udvarban, az összegyüjtött maradványok

A Forster Központ képviselői egy, a falakon kívül letámasztott védőtetőt megépítését képzeltek el. Ehhez kiindulópontként külföldi műemlékes homlokzati és tetőjavítás munkálatai során megépített védőtetők szolgáltak.

A Társasház elképzelését a Társasház 2014. szeptember hó 8-án az Építési hatósággal egyeztette.

A Forster Központ az épület megismerése céljából kezdeményezett egy bejárást. Erre 2014. szeptember hó 9-én került sor.

A Forster Központ, a Társasház és az Önkormányzat egyeztető tárgyalást folytatott 2014. szeptember hó 24-én a hogyan a „tovább”-ról. 

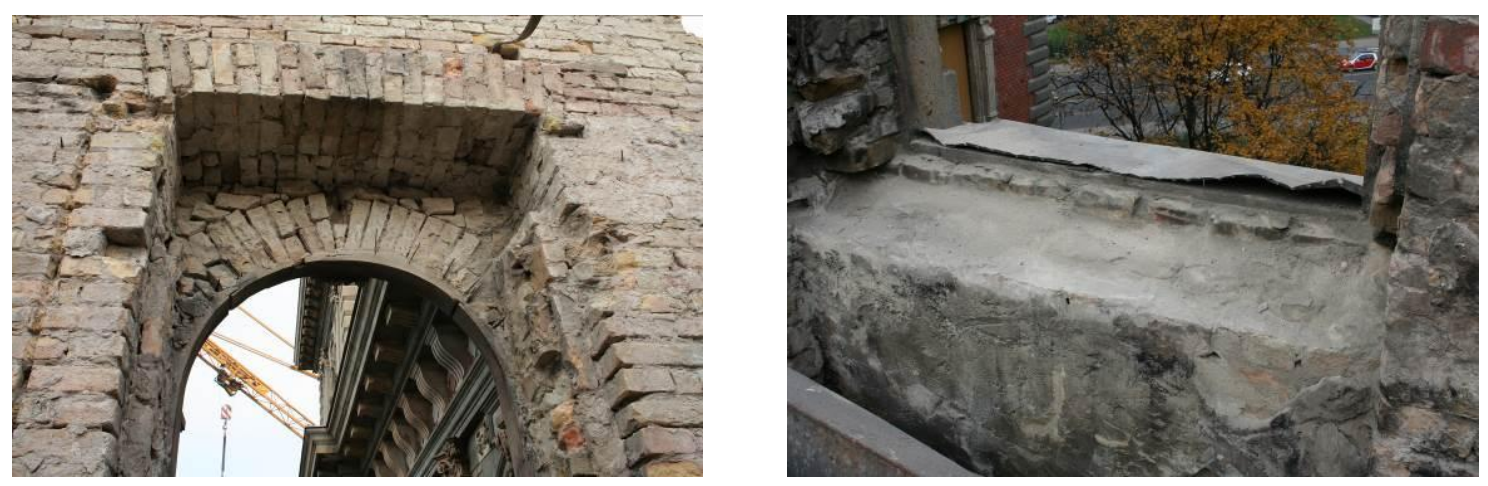

13. ábra: Ablaknyílás szemöldöke és párkánya

V. ker. Építésügyi és Örökségvédelmi Hivatal az épület állapotának felmérését, állékonyságának, használhatóságának igazolását, valamint az épület állagának védelmét határozatban írta elő.

A Társasház álláspontja az volt, hogy mind a kéményeket, mind pedig a légaknák falait el kell bontani úgy, hogy a lehető legegyszerűbb tetőidomú védőtető készülhessen. A Társasház a védőtető építése és kémények bontása kérdésében az Építési Hatósághoz fordult.

Az Építési Hatóság tudomásul vette a kialakult helyzetet. A védőtető építését támogatta. A kémények és a légudvarok falainak bontásához - kikötésekkel - hozzájárult.
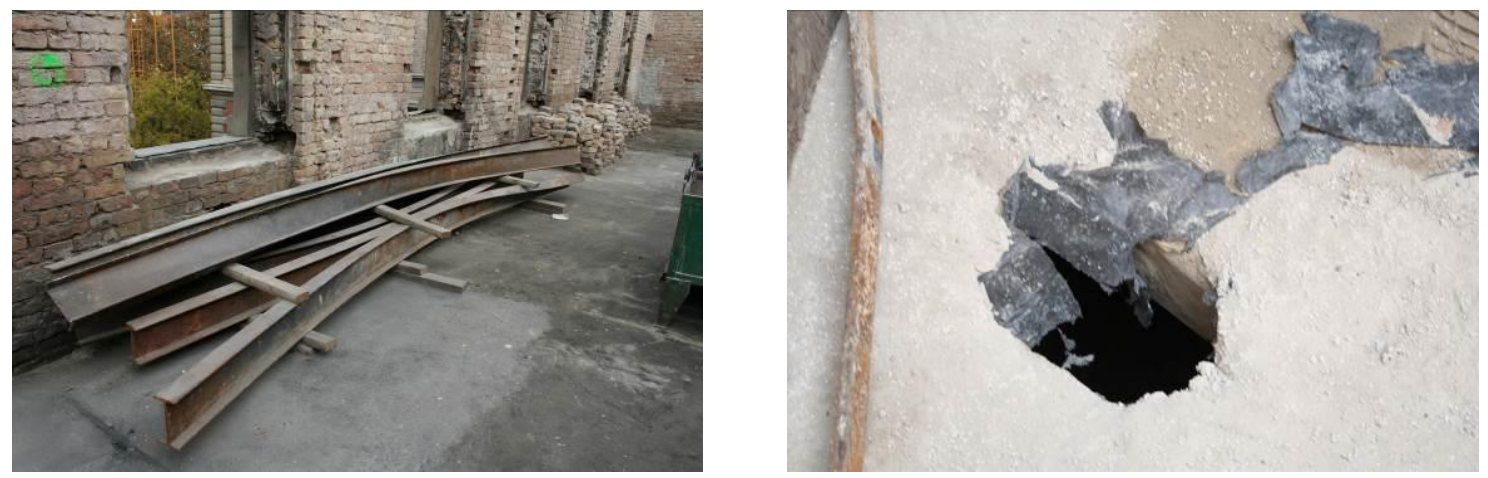

14. ábra: Deformálódott I tartók és átütött födém

\section{A kémények és a légaknák állapota}

A Kéményseprő Vállalt műszaki igazgatója a kémények állapotát kéményseprői szempontból rossznak ítélte meg: a kémények tüzeléstechnikai szempontból nem felelnek meg. Javasolta, hogy a kéményeket bontsák vissza.

Tartószerkezeti és épületszerkezeti szempontból az alábbi megállapítások születtek.

A tűzet követően a zárófödém és a tetőszerkezet megsemmisülésével a kémények stabilitása csökkent. Hosszú távon az életveszélyes helyzet potenciális forrása.

Az elvégzett vizsgálatok eredményét a következőkben lehetett összefoglalni. 
- Nyolc kémény ledőlt.

- Tíz kémény fedköve, alatta kb. egy-, két-, helyenként háromméternyi kéménytest szétmállott.

- A kémények jelentős hányadában (nagyjából a kémények 50-60 \%-ban) „vállban”, azaz a zárófödém síkjában, horony, többnyire kétoldali. Itt a kémény keresztmetszete 2/3-ra szűkül.

- A kémények egy kisebb hányadában (nagyjából a kémények 30-40 \%-ban) sok a lyuk, a mechanikai sérülés, repedés, nagyszámú a kifagyott, vagy károsodott tégla.
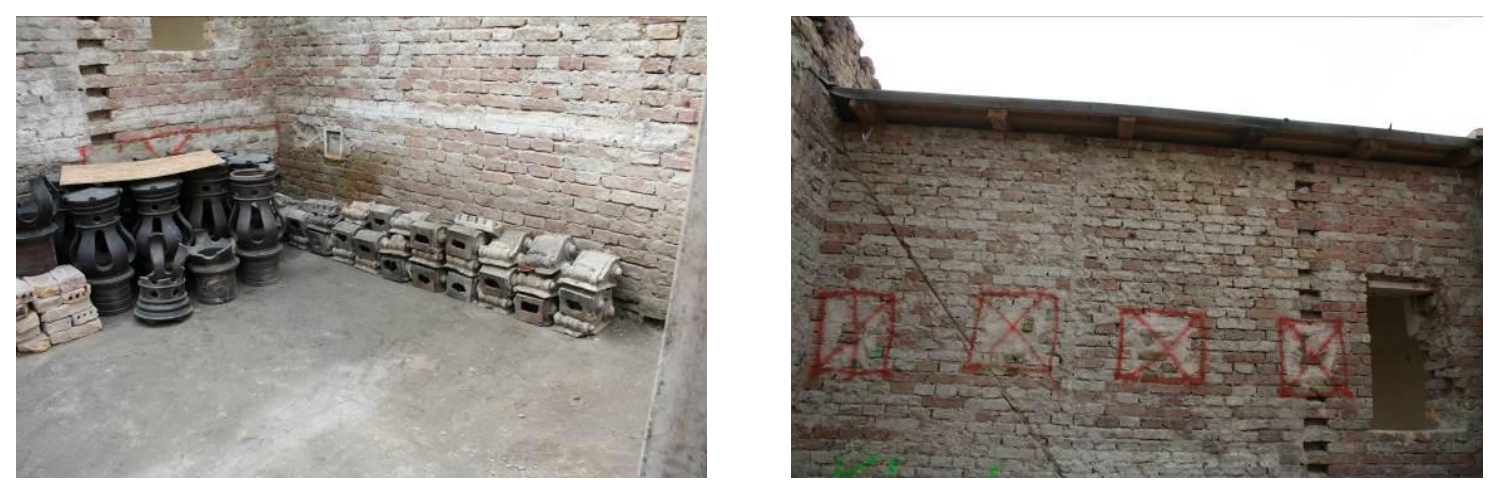

15. ábra: Összegyűjtött épületdíszek. Helyreállítás a lépcsőházi főfalban

A vizsgálatok alapján az alábbi következtetéseket kellett levonni.

- A kémények közül a nyolc ledőltet újjá kell építeni.

- A kémények döntő többsége (azaz a légudvar falába beépített, a légudvar falához hozzáfalazottak kivételével az összes) szilárdságtanilag nem állékony.

- A kémények jelentős része olyan mértékű károsodást szenvedett (nem a tűztől!), hogy falazott szerkezete javítás, pótlás, egyes esetekben átépítése nélkül nem tehető állékonnyá.

- A kémények falazó anyagának a döntő többsége olyan mértékben öregedett el, hogy azok közvetlenül (azaz bélelés nélkül) égéstermék elvezetésére nem alkalmasak.

A teendőkkel kapcsolatban a szakértői megállapítás a következő: a kéményeket

- vagy ki kell horgonyozni, a bontásra jelölt kéményeket, kémény-részeket vissza kell bontani, a hiányokat ki kell falazni, a lerepedt részeket le kell bontanai és újra kell falazni

- vagy el kell bontani.

A tűzet követően a zárófödém és a tetőszerkezet megsemmisülésével a légaknák önálló szerkezeti egységként állnak. Mivel a légaknák befoglaló mérete a $2 \times 2$ és $3 \times 3$ m között mozognak, ezért a közel 10 m magas építmények - elviekben - stabilnak tekinthetők.

Az elvégzett vizsgálatok eredményét a következőkben lehetett összefoglalni.

- A légaknák falazatairól a vakolat többé-kevésbé hiányzik, a megmaradt mállott.

- A légaknák falazatának felső 60-80 cm, helyenként 1,0 m magas részén a téglák már kilazultak, a fugák hiányosak, a téglák mozognak. Ez a hiba független a tűztől. A laza részek hosszú távon az életveszélyes helyzet potenciális forrásai.

- A légaknákban több helyen kisebb-nagyobb hiányok, törött téglák láthatóak. 
- Az Andrássy×Körönd sarkon álló légaknának a Körönd felöli fala tetejének a felső fél métere a tüzben leomlott.

- A merevítő pilléres aknákban (Szív utca közepe, Andrássy út baloldala, Körönd közepe) merevítő pillérek közötti falmezőkben részben ferde, részben függőleges repedések láthatók.

- A légaknák falában lévő nyílások többségének környezetében repedések láthatóak.

- Mind a fektető, mind az álló fugákban lévő habarcsréteg mállott.

- A Szív utcai szárny közepén, az Andrássy úti szárny bal oldali részén, valamint a Körönd elején álló légakna mind a négy falában láthatóak repedések, több helyen látható korábbi betonozás nyoma, a beton környezetében repedések, a nyílások környezetében több ferde repedés is látható. Ezek a légaknák szélterheléssel szemben kellő állékonysággal nem rendelkeznek, állapotuk életveszélyes.
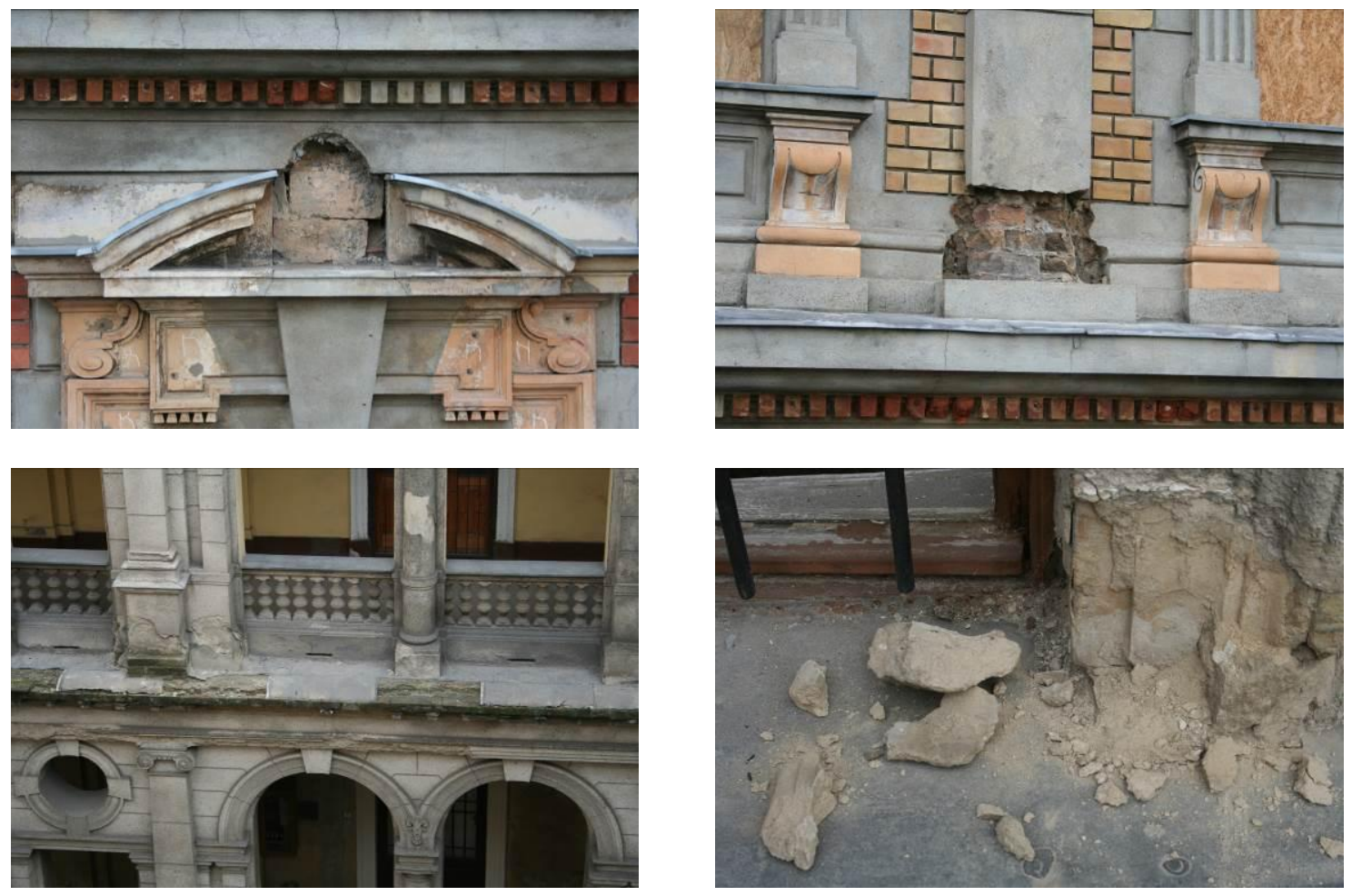

16. ábra: Hibák az épületdíszekben

A vizsgálatok alapján az alábbi következtetéseket kellett levonni:

- a légaknák a tűztől függetlenül károsodtak, azokat helyre kell állítani,

- a légaknákat a kémények elbontásával megbontani tilos.

A teendőkkel kapcsolatban a szakértői megállapítás a következő:

- vagy a hibás, hiányos, életveszélyes részeket át kell építeni,

- vagy a légaknákat - a beleépített kéményekkel együtt - el kell bontani. 

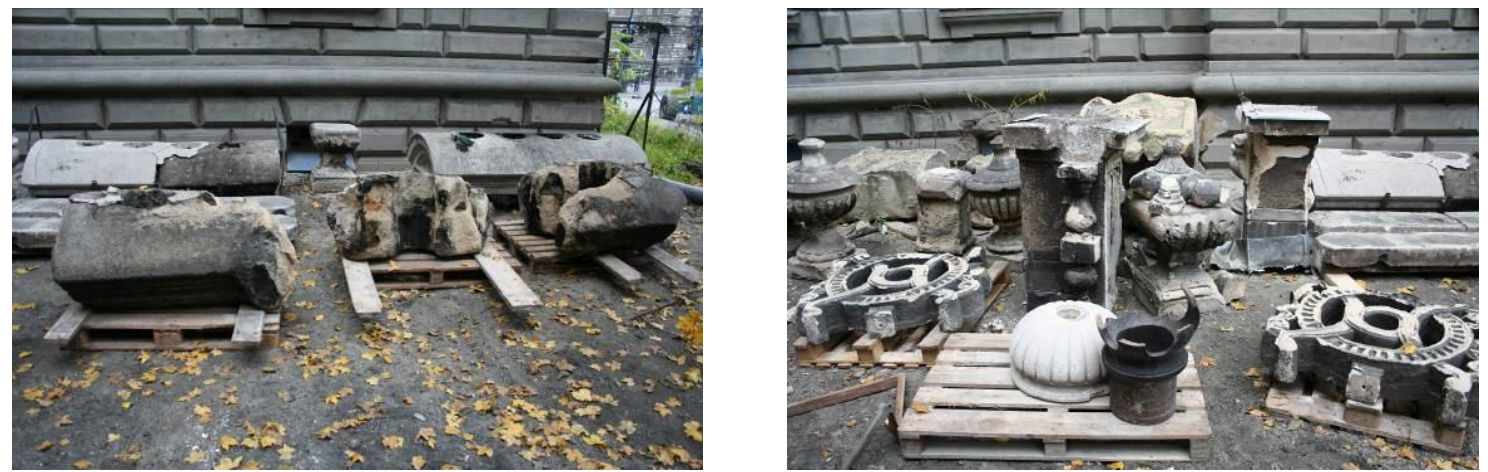

17. ábra: Néhány a deponált épületdíszek közül

\section{Az állagmegóvás előkészítése}

Megkezdődött az életveszély elhárítását követő lépése, az állagmegóvási munkálatok előkészítése. Ez további szempontok figyelembe vételét tesz szükségessé. Ezek a következők.

- A III. emeleti falazatok, párkányok és a II. emeleti födém az időjárástól megvédő tető építése.

- A III. emeleten átázott épületszerkezetek (párkányok, falak, födémek) temperálása, hogy az átázott épületszerkezetek ne fagyjanak el.

- A védőtető egyik koncepciója, hogy az épület fölött a lehető legkisebb magasságban készül el; azaz nem csak a kémények, hanem a légaknák (hét darab van) is a védőtető „megszakítását” teszi szükségessé. A kéményekés a légaknák bontása lehetővé tenné, hogy a típus szerkezetet alkalmazzanak, és ne kelljen a kémények és a légudvarok „kikerülésével” egyedi szerkezetet alkalmazni.

- A földszint, I. és II. emelet temperálása, hogy azokon belül ne keletkezzen fagykár.

- A földszint, I. és II. emelet fütése, meleg vízszolgáltatása az albetétek újbóli használatba vételéhez.

Az állagvédelem figyelembevételével a kivitelező által elvégzett munkák

Elsőnek a kémények visszabontásáról, másodszor a légaknák visszabontásáról született döntés: a Társasház a bontásuk mellett döntött, hogy az általuk elképzelt ideiglenes tetőszerkezet megépíthető legyen.

A Budapest Főváros VI. Kerület Terézvárosi Önkormányzat Testülete úgy döntött, hogy tartalékkeret terhére elvégezteti a kémények és légudvarok falainak bontását, hogy ezzel is segítse az Andrássy út 83-85. Társasház közösségét az épület állagának a megóvásában. A kémények és légudvarok falainak bontásához Megrendelő és a Kivitelező a Szerződést módosították.

A Szerződés Módosításában szereplő munkák:

- a visszabontandó kémények dísz fedköveinek bontása és deponálása,

- a kémények visszabontása a III. emeleti középfőfal falkorona síkjáig,

- a kémények falazó elemeinek elszállítása és lerakó helyen való leadása,

- a légudvarok falainak visszabontása a III. emeleti középfőfal falkorona síkjáig, 
- a légudvarok falainak használható falazó elemeinek deponálása a II. emelet feletti födémen, az építési törmeléknek minősülő anyagok elszállítása és lerakó helyen való leadása,

- a Szív utcai és a Felső erősor utcai épülettel határos tűzfalak visszabontása a III. emeleti középfőfal falkorona síkja fölött kb. 3 m-rel,

- a tűzfalak és a légudvarok falainak használható falazó elemeinek deponálása a II. emelet feletti födémen, az építési törmeléknek minősülő anyagok elszállítása és lerakó helyen való leadása.

A Kivitelező a feladatot maradéktalanul, baleset nélkül, elvégezte.

\section{A tűzesetet ismertető sorozat részei}

[1] G. Lámer (2015), A Köröndi tüz egy építőmérnök szemével. I. Rész. A tüz és állapotértékelés a tüzet követöen, MTEKR, Debrecen

[2] G. Lámer, A Köröndi tüz egy építômérnök szemével. II. Rész. Az életveszélyelhárítás I. üteme és állapotértékelés azt követően, Debreceni Egyetem, Műszaki Közlemények

[3] G. Lámer, A Köröndi tüz egy építőmérnök szemével. III. Rész. Az életveszélyelhárítás II. üteme és felkészülés az állagvédelemre

[4] G. Lámer, A Köröndi tüz egy építőmérnök szemével. IV. Rész. Az épület állapotának értékelése az életveszélyelhárítás II. ütemét követően

\section{A fényképek forrásai}

A fényképek a szerző felvételei. 